\title{
Penggunaan Pembangkit Listrik Tenaga Surya Sebagai Sumber Energi Pada Kapal Nelayan: Suatu Kajian Literatur
}

\author{
The Use of Solar Power Plant as Energy Sources on Fisherman Ships: A \\ Literature Review
}

\section{Made Aditya Nugraha*}

Program Studi Mekanisasi Perikanan, Politeknik Kelautan dan Perikanan Kupang, Indonesia
*Korespondensi: made.nugraha@kkp.go.id

\begin{abstract}
ABSTRAK
Seiring dengan kebutuhan dan berbagai jenis kapal yang berkembang, kebutuhan tenaga listrik di atas kapal akan sangat beragam. Pembangkit listrik di atas kapal selain menggunakan mesin diesel juga dapat memanfaatkan energi dari sinar Matahari sebagai sumber energi listrik alternatif. Potensi energi surya di Indonesia sebesar $4,8 \mathrm{kWh} / \mathrm{m}^{2}$. Energi baru dan terbarukan ini sesuai dengan tofografi Indonesia. Energi dari sinar Matahari di sekitar daerah ekuator begitu melimpah sehingga ketersediaannya selalu ada sepanjang tahun, kecuali pada saat hujan. Pemanfaatan energi Matahari dapat digunakan sebagai pengganti energi konvensional yang mulai terbatas dan harganya yang cukup mahal. Data yang disajikan dalam tulisan ini diperoleh dari publikasi, pabrikan, departemen pemerintah terkait, publikasi ilmiah dan publikasi lainnya. Pemanfaatan energi surya sebagai energi listrik dapat dilakukan dengan menggunakan panel surya yang dipasang di atas kapal. Energi listrik yang dihasilkan dapat digunakan untuk menghidupkan peralatan listrik dan lampu kapal di malam hari, dan digunakan sebagai alat bantu penangkapan ikan. Penggunaan PLTS juga dapat memberikan dampak positif kepada para nelayan, seperti peningkaatan kesehatan, ekonomi, kelestarian lingkungan dan membangun nelayan yang mandiri.
\end{abstract}

Kata Kunci: Pembangkit Listrik Tenaga Surya, Energi Terbarukan, Energi listrik, Energi Matahari, Kapal Nelayan,

\begin{abstract}
The need of electricity in every ship are very diverse. Power plants for using diesel as an engine can also come from sunlight as an alternative source of electrical energy. The measurement of solar energy in Indonesia is $4.8 \mathrm{kWh} / \mathrm{m}^{2}$. This renewable energy is in suitable for the Indonesian topography. Thus, the energy from the sunlight around the equator is so abundant that its availability is always available throughout the year, except when it rains. Utilization of solar energy can be used as a substitute for conventional energy which is starting to be limited and the price is quite expensive. Therefore, the data that are presented in this paper comes from publications, manufacturers, relevant official government documents, scientific publications and other publications. Utilization of solar energy as electrical energy can be done by using solar panels mounted in ships. The generated electricity can be used to turn on electrical equipment and send lights at night, and can be used as fishing aids. The use of solar power plant can
\end{abstract}


also have a positive impact on fishermen, such as improving health, economy, environmental sustainability, and building independent fishermen.

Keywords: Solar power plant, renewable energy, electrical energy, solar energy, fishing Boat

\section{PENDAHULUAN}

Luas lautan dibandingkan luas daratan di dunia mencapai kurang lebih 70 berbanding 30 . Ini menjadi tantangan tersendiri untuk negaranegara di seluruh dunia yang memiliki kepentingan laut untuk memajukan maritimnya. Laut sudah menjadi perhatian besar sejak zaman bahari. Laut diungkapkan sebagai hal yang sangat berarti dalam kitab-kitab suci maupun dalam mitos Yunani. Hal ini seiring dengan kemajuan teknologi dan peradaban manusia serta perkembangan lingkungan strategis yang menjadikan laut merangsang keingintahuan manusia dan menjadi signifikan serta dominan dalam mengantar kemajuan negara (Burhanuddin, 2013. Hardiana, 2019).

Indonesia secara geografis merupakan sebuah negara kepulauan dengan dua pertiga luas lautan lebih besar daripada daratan. Hal ini dapat dilihat dengan adanya garis pantai di hampir setiap pulau di Indonesia $( \pm$ $81.000 \mathrm{~km}$ ). Kelebihan ini menjadikan Indonesia menempati urutan kedua setelah Kanada sebagai negara yang memiliki garis pantai trepanjang di dunia. Selain merupakan tambahan kekayaan alam, laut juga memberikan fungsi tertentu kepada Indonesia, khususnya mempengaruhi kesejateran/ sosial ekonomi dan tingkat kemajuan di bidang IPTEK (Ilmu Pengetahuan dan Teknologi). Kekuatan inilah yang merupakan potensi besar untuk memajukan perekonomian Indonesia (Hardiana,
2019. Burhanuddin, 2013. Fauzi, 2010. Wibisono, 2005).

Indonesia merupakan salah satu negara maritim, sehingga Indonesia sebagian besar adalah lautan yang kaya akan hasil lautnya. Pernyataan ini didukung dari hasil Sidang Paripurna DPR RI 29 September 2014 mengenai UU Kelautan. Hal ini menjadikan langkah maju bangsa Indonesia dalam mencapai cita-cita sebagai Negara Maritim (Hardiana, 2019). Dalam mendukung kegiatan sebagai Negara Maritim, Presiden Joko Widodo memaparkan lima pilar sebagai upaya untuk mewujudkan poros maritim dunia. Kelima pilar tersebut merupakan bentuk tawaran kerja kerja sama Indonesia kepada dunia. Pertama, membangun kembali budaya maritim. Kedua, menjaga dan mengelola sumber daya laut dengan fokus membangun kedaulatan pangan laut melalui pengembangan industri perikanan, dengan menempatkan nelayan sebagai tiang utama. Ketiga, mengembangkan infrastruktur dan konektivitas maritim dengan membangun tol laut, deep seaport, logistic, industri perkapalan, dan pariwisata maritim. Keempat, mengembangkan diplomasi maritim dengan bersamasam menghilangkan sumber konflik laut. Kelima, membangun kekuatan pertahanan maritim (Portal Informasi Indonesia, 2019).

Kapal adalah salah satu sarana transportasi di laut. Kapal mempunyai keunggulan dalam pengangkutan, yaitu dapat lebih banyak dalam mengangkut muatan dibandingkan dengan sarana transportasi seperti 
mobil atau kereta api. Penggunaan kapal sebagai sarana transportasi memiiliki tingkat kecelakaannya relatif lebih sedikit karena dalam pembangunan kapal sudah dilengkapi sarana untuk pencegahan dan penanggulangannya (Kartini, 2013. Kertoraharjo, 2013).

Seiring dengan kebutuhan dan berbagai jenis kapal yang berkembang, kebutuhan tenaga listrik di atas kapal akan sangat beragam, sesuai dengan jenis kapal (kapal pengangkut muatan curah, padat, tanker, peti kemas, mobil, penyebrangan, penumpang, kapal pendukung kegiatan lepas pantai, dan lainnya). Untuk memenuhi kebutuhan listrik, digunakan dua atau tiga generator yang didukung oleh sebuah generator darurat atau seperangkat baterai darurat (Handoyono, 2017). Berdasarkan data dari Badan Pusat Statistik Indonesia pada Tahun 2017, jumlah perahu/kapal menurut jenis kapal dengan perahu motor tempel berjumlah 181.178 buah, dan jumlah perahu dengan jenis kapal motor berjumlah 171.744 (BPS, 2019).

Pembangkit listrik di kapal umumnya digerakan oleh mesin penggerak dari mesin diesel, turbin uap, dan turbin gas. Jadi penggunaan mesin penggerak generator adalah sebagai mesin yang melakukan proses konversi energi primer (bahan bakar) yang diubah menjadi energi mekanik penggerak generator (tenaga putar), yang kemudian energi putar ini diubah oleh generator menjadi energi listrik (Handoyono, 2017).

Di kapal, pusat tenaga listrik atau umumnya disebut pesawat bantu listrik (auxiliary engine, $A E$ ) atau mesin diesel pembangkit listrik (diesel engine generator, DEG) yang ditempatkan pada kamar mesin, sesuai persyaratan dari Biro
Klasifikasi Kapal harus ada minimum dua unit atau ditambah dengan pembangkit tenaga listrik darurat (emergency diesel engine generator). Karena itu instalasi listrik yang terpasang di atas kapal sepenuhnya harus mendapatkan persetujuan Klasifikasi Kapal mulai dari pada saat kapal baru pertama kali dibangun di atas galangan kapal (Danajat, 2016).

Pembangkit listrik di atas kapal selain menggunakan mesin penggerak dari mesin diesel juga dapat memanfaatkan energi dari sinar matahari sebagai sumber energi listriknya. Hal ini dapat digunakan sebagai alternatif sumber energi listrik disebabkan karena kebutuhan akan energi listrik terus meningkat setiap tahun. Permasalahan ini hampir terjadi di seluruh Indonesia. Energi baru dan terbarukan yang sesuai dengan tofografi Indonesia adalah energi dari sinar Matahari. Indonesia terletak di sekitar daerah ekuator sehingga menyebabkan ketersediaan sinar Matahari sepanjang tahun. Energi Matahari dapat digunakan sebagai pengganti energi konvensional yang mulai terbatas dan harganya yang cukup mahal. Potensi energi surya di Indonesia sebesar 4,8 $\mathrm{kWh} / \mathrm{m}^{2}$, menyebabkan Indonesia berpotensi untuk memanfaatkan energi surya sebagai sumber energi listrik (Nugraha, 2013. Nugraha, 2018. Nugraha, 2019. USAID, 2016). Pemanfaatan energi surya sebagai energi listrik dapat dilakukan dengan menggunakan Solar PV yang dipasang di atas kapal. Energi listrik yang dihasilkan dapat digunakan untuk menghidupkan peralaan listrik dan lampu kapal di malam hari, dan digunakan sebagai alat bantu penangkapan ikan. Penggunaan energi surya sebagai sumber energi listrik diharapkan dapat meningkat- 
kan kesehatan (sanitasi di dalam ruang mesin) para KKM dan masinis, serta mengurangi pengunaan energi fosil yang kurang baik untuk lingkungan (Santhiarsa, 2005. Nugraha, 2019).

Tulisan ini mencoba untuk meninjau ketersediaan sistem dan penggunaanya di atas kapal. Ketersediaan yang dibahas pada tulisan ini adalah tentang kapasitas sistem yang akan dipasang.

\section{METODE PENELITIAN}

Data yang disajikan dalam tulisan ini diperoleh dari publikasi, pabrikan, departemen pemerintah terkait, publikasi ilmiah dan publikasi lainnya. Inforamasi tentang pemanfaatan PLTS di atas kapal penangkap ikan sebagai sumber energi listrik diharapkan dapat dijadikan salah satu rujukan cepat bagi anggota masyarakat khususnya nelayan yang tertarik untuk memanfaatkan tenaga Matahari sebagai sumber energi listrik guna mengembangkan pembangkit listrik terbarukan dan ramah terhadap lingkungan.

\section{HASIL DAN PEMBAHASAN}

\section{Penggunaan PLTS Dalam Dunia Perikanan}

Secara umum pada sebuah kapal terdapat mesin diesel pembangkit listrik sebanyak dua unit dan satu pembankit listrik listrik darurat. Mesin ini digunakan sebagai sumber pembangkit energi listrik di atas kapal.

Penggunaan penerangan di atas kapal adalah untuk memastikan suatu lingkungan kerja yang aman, sekaligus kenyamanan saat beban tugas di dalam hunian kapal.
Sejumlah daya listrik dalam proposi yang memadai akan sangat berguna untuk kegiatan di kapal. Penerangan pada tempat di atas dek, di dalam kamar mesin, di dalam ruang hunian atau akomodasi untuk memenuhi tingkat persyaratan khusus untuk penerangan diberikan oleh berbagai jenis penerangan yang dirancang untuk bekerja dengan aman.

Penggunaan energi listrik di atas kapal semula digunakan untuk penerangan saja, tetapi kemudian digunakan juga sebagai lampu navigasi sewaktu kapal berlayar dalam keadaan cuaca buruk dan gelap. Kapasitas daya penggunaan cahaya yang digunakan akan sangat bervariasi dari beberapa Watt sampai dengan berkekuatan kilo-Watt yang sangat terang untuk penerangan di atas dek dan lampu untuk melakukan pencarian sesuatu (searching light). Jumlah cahaya yang dapa menembus suatu ruangan atau tempat tertentu dapat diukur dengan sebuah alat pengukur kekuatan cahaya (luminance meter).

Penerangan dalam sebuah kapal sangat penting. Tanpa adanya penerangan, jalannya operasi pusat listrik akan terganggu. Oleh karena itu perlu adanya pasokan daya untuk penerangan sedapat mungkin tidak padam.

Penggunaan cahaya lampu untuk penangkapan ikan di Indonesia dewasa ini telah berkembang cukup pesat, sehingga di tempat-tempat di mana terdapat kegiatan perikanan hampir dapat dipastikan bahwa daerah tersebut terdapat lampu yang digunakan untuk usaha penangkapan ikan. Pada tahun 1950-an penggunaan lampu untuk kegiatan penangkapan ikan sangat terbatas dan terpusat pada suatu daerah tertentu. Penggunaan cahaya listrik dalam skala industri 
penangkapan ikan pertama kali dilakukan di Jepang pada tahun 1990 untuk menarik perhatian berbagai jenis ikan. Selanjutnya terus berkembang hingga sekarang.

Perkembangan light fishing di Indonesia selama 20 tahun terakhir telah banyak dilakukan. Untuk penggunaan PLTS sebagai sumber energi listrik dapat dilihat pada penggunaan di bagan apung. Proses transformasi energi dalam PV dilakukan melalui konversi fotovoltaik oleh sel surya. Hasil energi listrik ini digunakan untuk menghidupkan lampu sebagai pemikat atau penarik perhatian ikan. Beberapa keuntungan dari pengoperasian PLTS ini adalah energi yang digunakan tersedia melimpah dan gratis, sistem mudah diinstalasi sehingga kapasitasnya dapat diperbesar sesuai dengan kebutuhan, perawatannya mudah, bekerja secara otomatis dan keandalan sistem yang tinggi.

Penggunaan PLTS di atas kapal tentunya diharapkan dapat memberikan manfaat yang baik terhadap para pelaku sektor perikanan. Manfaat tersebut kurang lebih dapat memberikan meningkatkan sanitasi di dalam ruangan dan secara ekonomi dapat mengurangi penggunaan bahan bakar solar sebagai bahan bakar generator sebagai sumber pembangkit listrik (Nugraha, 2013. Nugraha, 2019).

Sebuah sistem PLTS terdiri dari panel surya, serangkaian pengatur pengisian, penyimpanan energi listrik (baterai), inverter, pengkabelan dan konektor, serta beberapa perlengkapan mekanis lainnya. Perkembangan teknolgi ini telah mampu menghasilkan sistem PLTS yang ekonomis dan handal. Industri nasional sudah mampu memproduksi semua komponen dari sistem PLTS.
Secara segi kualitas, sebagian komponen PLTS yang beredar di pasaran sudah memenuhi standar uji BPPT, meskipun masih terdapat beberapa komponen yang belum terstandar. Dari hasil uji yang telah dilakukan disebutkan bahwa 52\% modul surya yang diuji sudah memiliki kapasitas sebesar nilai nominalnya, bahkan lebih (USAID, 2016).

Panel surya atau PV adalah komponen dari PLTS yang berfungsi untuk mengubah sinar Matahari menjadi energi listrik (Nugraha, 2013. Nugraha 2018. Nugraha, 2019. Kumara, 2010). Di Indonesia sudah terdapat beberapa perusahaan yang dapat memproduksi panel surya, antara lain PT. LEN, PT. Adyawinsa Electrical \& Power, PT. Surya Utama Putra, PT. Swadaya Prima Utama, PT. Azet Lestari, PT. Wijaya Karya Industri Energi, PT. Jembo Energindo, PT. Sky Energy Indonesia, PT. Sankeindo, PT. Canadian Solar Indonesia, PT. Skytech Indonesia (Putri, 2017). Beberapa diantaranya, sudah melakukan ekspor ke berbagai negara. Dari sisi bahan baku Indonesia memiliki bahan silica yang melimpah yang merupakan komponen penting dalam pembuatan panel surya. Pemerintah pusat juga telah menyatakan kesiapan untuk mendukung pembangunan pabrik sel dan panel surya untuk dapat memenuhi kebutuhan kebutuhan dalam negeri (Kumara, 2010). Tabel 1 adalah produsen dari panel surya yang beredar di Indonesia beserta negara asal. Sedangkan untuk kapasitas keluaran dan spesifikasi teknisnya sudah tersedia dari ukuran $5 \mathrm{Wp}-280$ Wp di pasar nasional Indonesia (Kumara, 2010. Putri, 2017). 
Tabel 1. Produsen Solar Panel di Indonesia

\begin{tabular}{|c|c|c|}
\hline \multirow{2}{*}{$\begin{array}{l}\text { Perusahaan } \\
\text { PT. LEN Industri }\end{array}$} & Negara & Alamat Situs \\
\hline & Indonesia & $\underline{\text { www.len.co.id }}$ \\
\hline PT. Adyawinsa & Indonesia & www.adyasolar.com \\
\hline \multicolumn{3}{|l|}{ Electrical \& Power } \\
\hline PT. Surya Utama Putra & Indonesia & $\underline{\text { www.suryautamaputra.co.id }}$ \\
\hline $\begin{array}{l}\text { PT. Swadaya Prima } \\
\text { Utama }\end{array}$ & Indonesia & www.isolar-1.com \\
\hline PT. Azet Lestari & Indonesia & $\underline{\text { www.azetsurya.id }}$ \\
\hline $\begin{array}{l}\text { PT. Wijaya } \\
\text { Industri Energi }\end{array}$ & Indonesia & www.wikaenergi.com \\
\hline PT. Jembo Energindo & Indonesia & http://jembo.co.id \\
\hline $\begin{array}{l}\text { PT. Sky Energy } \\
\text { Indonesia }\end{array}$ & Indonesia & www.sky-energy.co.id \\
\hline PT. Sankeindo & Indonesia & $\underline{\text { www.sankenindo.co.id }}$ \\
\hline $\begin{array}{l}\text { PT. Canadian Solar } \\
\text { Indonesia }\end{array}$ & Indonesia & \\
\hline PT. Skytech Indonesia & Indonesia & $\underline{\text { www.sky.co.id }}$ \\
\hline Shinyoku & Indonesia & $\underline{\text { https://shinyoku.com }}$ \\
\hline BP Solar & Inggris & www.bp.com \\
\hline Bright Scenery & Cina & http://brightsccenery.en.alibaba.com \\
\hline elSOL & Jerman & $\underline{\text { www.El-SOL-tec.de }}$ \\
\hline Kyocera & $\begin{array}{l}\text { Amerika, } \\
\text { Australia }\end{array}$ & $\underline{\text { www.kyocerasolar.com }}$ \\
\hline New Tomorrow & Jerman & www.new-tomorrow.de \\
\hline OKI & Cina, Jerman & $\underline{\text { www.oki.com }}$ \\
\hline Sharp & Jepang & $\underline{\text { www.sharp-solar.com }}$ \\
\hline SunRise Solartech & Cina & WwW.srsolaretech.cn \\
\hline SunSeap & $\begin{array}{l}\text { Singapura, } \\
\text { Jerman }\end{array}$ & www.sunseap.com \\
\hline Time Valiant & Cina & www.thxny.com \\
\hline Zytech & Spayol & www.zytech.es \\
\hline
\end{tabular}

Baterai merupakan komponen PLTS yang diperlukan untuk menyimpan energi listrik yang dihasilkan oleh panel surya (Nugraha, 2013. Nugraha, 2018. Nugraha, 2019. Kumara, 2010). Penggunaan baterai sebagai penyimpan energi dapat digunakan untuk menghidupkan peralatan listrik. Ketersediaan baterai secara nasional sudah tersedia dengan baik dari sisi kapasitas dan distribusi. Keberadaan ini didukung oleh aplikasi baterai yang sangat luas di berbagai bidang, namun harus tetap diperhatikan bahwa karakteristik baterai untuk PLTS berbeda. Beberapa produk baterai yang tersedia di dalam negeri dan sering dipergunakan dalam PLTS antara lain Delkor, Fiamm, GS, Haze, Hitachi, Incoe, Leoch, Massiv, Mastervolt, Panasonic, PowerKingdom, Rita, Trojan, dan Yuasa. Dalam pengujian yang dilakukan sejak tahun 2006 sampai dengan 2008 oleh B2TE, ditemukan bahwa hampir $75 \%$ baterai yang diuji telah memenuhi persyaratan uji dan berhak untuk 
memperoleh uji standar (Kumara, 2010).

Inverter adalah merupakan peralatan yang berfungsi untuk merubah tegangan arus searah $(D C)$ menjadi arus bolak-balik $(A C)$. Pada PLTS, inverter dihubungkan ke baterai yang memiliki sistem kerja $D C$, yang selanjutnya akan diubah menjadi tegangan $A C 220 \mathrm{~V}, 50 \mathrm{~Hz}$. Tegangan keluaran ini disesuaikan dengan tegangan yang diharapkan, sehingga memudahkan dalam pengaplikasiannya di lapangan.

Penghantar atau kabel dan material mekanis lainnya yang diperlukan dalam PLTS sudah tersedia secara luas di Indonesia. Hal ini disebabkan Karena industri tersebut sudah baik dan mapan. Komponen pendukung lainnya seperti lampu LED, Lampu Hemat Energi, TV, dan peralatan elektronik lainnya baik yang menggunakan listrik $A C$ atau $D C$ sudah tersedia di pasaran Indonesia.

Pengujian Komponen Sistem PLTS di Indonesia

$\begin{array}{cr}\text { Laboratorium } & \text { Komponen } \\ \text { Sistem } & \text { Fotovoltaik }\end{array}$ merupakan salah satu laboratorium uji di lingkungan Balai Besar Teknologi Energi (B2TKE-BPPT), yang telah terakreditasi ISO/IEC 17025 melalui KAN sejak tahun 2004. Hingga saat ini LPKSF merupakan laboratorium yang berfungsi dalam menunjang control kualitas produk komponen sistem fotovoltaik di Indonesia. Pelayanan uji ini meliputi: pengujian modul fotovoltaik, pengujian baterai, pengujian kontroler $(B C R)$, pengujian lampu $T L D C$, pengujian inverter dan pengujian sistem PLTS. Berbagai komponen sistem Fotovoltaik yang biasa digunakan pada sistem pembangkit Fotovoltaik dapat diuji di
B2TKE Serpong, Tangerang Selatan (Lande, 2017. Faradilla, 2017).

\section{Ketersediaan Sistem PLTS di Indonesia}

Sesuai dengan Perpres no 5 Tahun 2006, tentang Kebijakan Energi Nasional, dialokasikan untuk energi terbarukan di tahun 2025 penggunaan energi baru dan energi terbarukan lainnya khususnya biomassa, nuklir, tenaga air, tenaga surya dan tenaga angin menjadi lebih dari 5\%. Dengan alokasi tersebut, maka akan diperlukan banyak sekali komponen sistem PLTS. Diperkirakan akan diperlukan sekitar 1500 MWp panel surya di tahun 2025. Untuk antisipasinya mulai saat ini diperlukan persiapan untuk menyambut program tersebut (Nugraha, 2013. Nugraha, 2018. Faradila, 2017). Perkembangan ini tidak lepas dari peranan distributor sebagai perantara antara produsen dan konsumen yang ingin memanfaatkan teknologi PLTS. Untuk pembelian komponen sistem PLTS saat ini sudah sangat mudah ditemui dan diperoleh, karena sudah banyak online shop (Tokopedia, Bukalapak, dll) yang memudahkan para konsumen untuk mencari keperluan tersebut.

\section{Rencana Penggunaan PLTS Sebagai Sumber Energi Listik di Kapal}

Sel surya adalah sebuah alat konversi energi yang mengubah bentuk energi surya menjadi energi listrik. Energi yang dihasilkan oleh sel surya adalah yang paling ramah lingkungan, namun lahan instalasi yang diperlukan sangat luas. Selain itu, energi surya sangat tergantung pada besarnya intensitas sinar matahari sehingga kontinuitasnya menjadi masalah tersendiri. Dalam 
upaya untuk menjadikan energi surya sebagai pembangkit tenaga listrik, maka beberapa kelemahan tersebut harus diperbaiki, agar menghasilkan arus listrik yang kontinu dan ukuran yang seringkas mungkin (Nugraha, 2013. Nugraha, 2018. Kumara, 2010. Faradila, 2017).

Penggunaan listrik dengan menggunakan PLTS sebagai sumber penerangan memberikan beberapa dampak yang baik, seperti: peningkatan ekonomi, kesehatan, keamanan dan kenyamanan penggunanya (Nugraha, 2013. Nugraha, 2019). Oleh karena itu untuk sebuah kapal yang dulunya menggunakan generator sebagai sumber energi listriknya bisa menggunakan PLTS sebagai sumber energi penggantinya.

Sebuah kapal dengan rata-rata beban listrik sebesar $2.160 \mathrm{Wh} /$ hari dan menggunakan panel surya dengan ukuran 200Wp sebanyak 3 buah dapat mensuplai kebutuhan listrik kebutuhan listrik kapal tersebut selama 12 jam berlayar di malam hari. Beban listrik per hari ini terdiri dari penggunaan lampu $840 \mathrm{~W}$, radio telekomunikasi $960 \mathrm{~W}$, dan alat elektronik lainnya sebesar $360 \mathrm{~W}$.

Saat ini banyak sekali permintaan kepada industri swasta nasional untuk menyediakan sistem PLTS oleh beberapa Departemen Teknis. Meningkatnya permintaan di Indonesia disebabkan adanya program pemerintah dalam melakukan diversifikasi suplai energi. Hal ini tentu saja akan sangat menjadi nilai positif untuk masyarakat nelayan sebagai salah bentuk keperdulian terhadap lingkungan, kesehatan dan perekonomian.

\begin{tabular}{lccr}
\multicolumn{2}{c}{ Penggunaan } & PLTS & sebagai \\
sumber energi & listrik & sebagai \\
pengganti & genset & di atas & kapal
\end{tabular}

tentunya harus diperhatikan kembali. Investasi awal dan perawatan sistem ini perlu adanya perhatian khusus. Penyediaan PLTS untuk kapal perikanan diharapkan tidak berasal dari bantuan dari pemerintah. Hal ini dalam usaha untuk membangun nelayan yang mandiri dan sebagai bentuk peduli terhadap lingkungan.

\section{KESIMPULAN}

Penggunaan PLTS sebagai sumber energi listrik untuk dapat diterapkan di dunia perikanan khususnya sebagai sumber energi listrik di atas kapal sangat memungkinkan. Hal ini didukung oleh ketersediaan dari sistem PLTS itu sendiri di Indonesia.

Penggunaan PLTS juga dapat memberikan dampak positif kepada para nelayan. Dampak ini seperti peningkaatan kesehatan, ekonomi, kelestarian lingkungan dan membangun nelayan yang mandiri.

\section{SARAN}

Penggunaan energi terbarukan khususnya PLTS dalam bidang transportasi laut sudah lumayan banyak dipergunakan, namun penggunaan ini hendaknya disesuaikan dengan kebutuhan listrik dari kapal dan kemampuan dari nelayan. Investasi yang besar dan biaya perawatan juga menjadi tantangan dalam pemanfaatan PLTS di atas kapal.

\section{DAFTAR PUSTAKA}

BPS. 2019. Jumlah Perahu/Kapal Menurut Provinsi dan Jenis Perahu/Kapal untuk Perikanan Laut, 2000-2016. https://.bps.go.id/ 
Burhanuddin, A.I, Nessa, M. N, Niartiningsih, A. 2013. Membangun Sumber Daya Kelautan Indonesia; Gagasan dan Pemikiran Guru Besar Universitas Hasanuddin. Bogor: IPB

Danajat, I. 2016. Mesin Bantu Penangkapan Ikan, Kelas XI. Jakarta: Penerbit Buku Maritim Djangkar

Faradilla, A. 2017. Pengujian PV dan Pendukungnya. Balai Besar Teknologi Konversi Energi.

Fauzi, A. 2010. Ekonomi Perikanan. Jakarta: PT. Gramedia

Handoyono, J J. 2017. Teknik Kelistrikan Kapal; Ahli Teknik Tingkat III. Jakarta: Buku Maritim Djangkar

Hardiana, I. 2019. Potensi Indonesia Sebagai Negara Maritim. http://www.perumperindo.co.id

Kartini, E. 2013. Pengetahuan Kapal Laut dan Muatannya. Yogyakarta: Deepubish

Kertoraharjo, R.S.P. 2013. Kapal Perikanan (Fishing Vessel). Jakarta: PT. Gramedia

Kumara, N S. 2010. Pembangkit Listrik Tenaga Surya Skala Rumah Tangga Urban dan Ketersediaannya di Indonesia. Teknologi Elektro Vol. 9 No 1, Januari - Juni 2010.

Lande, N M. 2017. Pengujian Inverter Di Laboratorium Pengujian Komponen Sistem Fotovoltaik, B2TKE-BPPT. Balai Besar Teknologi Konversi Energi.

Nugraha, I M A. 2013. Studi Dampak Ekonomi dan Sosial PLTS Sebagai Listrik Pedesaan Terhadap Masyarakat Desa ban Kubu Karangasem. Prosiding CSGTEIS 2013

Nugraha, I M A. 2018. Optimalisasi Pemasangan Panel Solar Home
System Untuk Kehidupan Masyaraka Pedesaan di Ban Kubu Karangasem. Majalah Ilmiah Teknologi Elektro, Vol 17 No. 1, Januari-April 2018.

Nugraha, I M A. 2019. Solar Home System Dapat Meningkatkan Kesehatan Masyarakat Desa Ban di Bali. Bali Health Journal, Vol. 3 No 1. 2019

Portal Informasi Indonesia. 2019. Kebijakan Nasional; Indonesia Poros Maritim Dunia. https://www.indonesia.go.id

Putri, N. 2017. Pabrik Panel Surya Yang Ada di Indonesia. https://janaloka.com/pabrikpanel-surya-yang-ada-diindonesia/

Santhiarsa, I G N N. Kusuma, I G B W. 2005. Kajian Energi Surya Untuk Pembangkit Tenaga Listrik. Teknologi Elektro, Vol. 4 No. 1, Januari - Juni 2005.

USAID.Rencana Pengembangan Grid Pulau Kecil Solar PV dan PV Diesel di Provinsi Nusa Tenggara Timur. 2016

Wibisono, M.S. 2005. Pengantar Ilmu Kelautan. Jakarta: PT. Grasindo 
